\title{
Measuring Customer Attitudes Toward Single Vs. Hybrid Retail Formats: Impact Of Gender And Brand Name Familiarity
}

Yoon C. Cho, (E-mail: yoonji22e@gmail.com), KDI School Of Public Policy And Management, Korea

\begin{abstract}
Numerous researchers have focused on the issues of online businesses, but not many studies have addressed the issues of catalogue business expansion to online business. This study raises questions that customer attitudes toward those companies offering a combination of catalogue and e-business differ from those offering catalogue or e-business only. A statistical report (www.thestandard.com 2002) shows that the profitability of catalogue business with online is about 79\% in 2002, while the profitability of pure e-business is about 36\%. In addition, this study explores variables, such as gender and brand name impact, and also consumer satisfaction, factors that are highly related to the customers' willingness to purchase. Experiments with survey methods have been applied to analyze these research issues. The major findings provide implications and offer suggestions to various retail formats, such as catalogue business, e-business, and e-business including catalogue sales.
\end{abstract}

\section{Introduction}

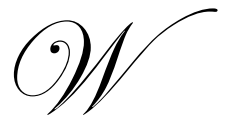

ith the Internet presence, many firms have changed their retail formats from a single retail format to hybrid-channel operations. Presently, businesses often combine retail formats extending from traditional "brick-and-mortar" to "click-and-mortar," "click-and-mortar" to "brick-and-mortar," or catalogue to "click-and-mortar." Pure plays (i.e., pure online business such as Yahoo) also expand retail formats from single to multi-formats. Both online and catalogue businesses, as direct marketing, replicate most of the physical activities that take place in the market place to the point where increasing electronic commerce usage is shifting companies from those traditional market places to new market spaces. With the development of the Internet, catalogue businesses are combining those retail formats with e-commerce by extending the market. Sales for both online and catalogue businesses have been increasing during the past several years. According to the Census Bureau of the Department of Commerce, sales for electronic commerce reached up to $\$ 15.7$ billion with an increase of $23.1 \%$ from the second quarter of 2003. Based on the Direct Marketing Association, catalogue sales also have increased each year, e.g., $8.9 \%$ from $\$ 110.2$ billion in 2000 to $\$ 120$ billion in 2001 .

The purpose of this study is to explore the research question that customer attitudes toward single avenue retail business, such as pure catalogue or exclusive e-business, differ from hybrid-channel business, such as catalogue with e-business. A particular concern of this study is how customers' attitudes toward sensory products that cannot be touched, heard, seen, or smelled prior to making a purchase decision differ in various direct marketing situations. This study also examines the impact of other factors, such as brand familiarity and gender impacts to measure the effects of different retail formats. Therefore, the particular concern of this study investigates three factors: i) how a consumer's expectations and satisfaction for catalogue and e-businesses are affected by the brand name familiarity: well-known vs. less well-known brand name; ii) how a consumer's gender affects attitudes toward different retail formats; and iii) how various consumer expectations affect the willingness to purchase the product/service and the customer's perceived satisfaction. 


\section{Literature Review}

\subsection{Impacts Of Hybrid Retail Formats}

A previous study (Mathwick, Malhotra, and Rigdon 2001) states that merchants are combining print and online catalogue operations to replace pure-play Internet models that have encountered market difficulty. Another study by Hansotia and Rukstales (2002) discusses key challenges that retailers face as they try to build customer relationships and motivate customers to shop more frequently at their online stores and through their catalogues. Catalogue businesses with an online presence showed greater profitability than pure online businesses (Direct Marketing Association 2002). The profitability is even higher than store based businesses with an online business presence.

Online and catalogue businesses are similar in terms of interactivity (i.e., two-way communication between the customer and retailer), while the two retail formats differ in terms of the degree of interactivity, consideration set, and perceived convenience, etc. Both electronic commerce and catalogue businesses are known as Interactive Home Shopping (IHS) businesses (Alba et al. 1997). This study questions how consumer attitudes toward catalogue, ebusiness, or hybrid-channel formats are different, while both retail formats have similarities, such as direct marketing and interactivity, etc. According to Mohammed, Fisher, Jaworski, and Cahill (2004), businesses with multi-channel formats provide hybrid value by offering enabling ease of access and radically extending reach values.

\subsection{Impacts Of Retail Formats: Catalogue vs. E-Commerce}

In this study, the author posits that customers' attitudes toward each retail format - catalogue vs. e-businesses. The similarities and differences between retail formats (e.g., between catalogue and e-businesses) have been investigated in the previous study by Alba et al. (1997). While there are many similarities between catalogues and Internet retailers, Alba et al. (1997) suggests that quality of information for selecting from the consideration set may differ between catalogue businesses and e-businesses.

Catalogue and e-businesses are similar in that consumers for both retail formats cannot physically try, touch, see, or hear the products before they purchase them. A study by Kiely (1996) states that the impact of interactive home shopping depends on the requirements of the consumers' physical presence. Figueiredo (2000) investigated the impact of product category on e-business. Figueiredo (2000) has suggested the continuum on the Web, and introduced four product categories that are used in the online environment: commodity products (e.g., oil, paper clips), quasicommodity products (e.g., books, CDs, videos, or toys), look-and-feel goods (e.g., suits, furniture, model homes, etc.), and look-and-feel goods with variable quality (e.g., arts, produce, etc). Figueiredo (2000) suggested that online consumers are not likely to purchase products when the quality of the product is not easily judged on the Web. Based on Figueiredo (2000), e-businesses dealing with those product categories, such as look-and-feel goods and look-andfeel goods with variable quality are encouraged to employ competitive strategies, such as building brand awareness, managing customization, and advanced technology, etc. According to Cho and Ha (2004), consumers' attitudes regarding price sensitivity and the subjective requirement of advanced. While pure e-business relies solely on customer interactions via a computer and telecommunications infrastructure for the purpose of advertising, promoting, and selling products and services online (Cho and Fjermestad 2005), pure catalogue business relies on customer interactions via printed magazines. IHS increases interactivity as a continuous construct capturing the quality of twoway communication between two parties (Alba et al. 1997); however, it blocks customers' sensory attributes that include seeing, touching, feeling, smelling the product.

This study has posited that those product classifications are not only applied to e-business but also catalogue business as consumers for both retail formats has the limitation of physical presence. Consumers' decision-making and choice behaviors for both retail formats might be similar depending on the product categories, while catalogue shopping appears to entertain and delivers visual appeal that is either missing from or was not noticed in the online context (Mathwick et al. 2001). This study considers sensory product to measure consumer attitudes toward different retail formats. While customers for both catalogue and e-businesses cannot physically touch/see/hear/smell the product before making a purchase decision, product categories sold through the two retail formats are quite different. 


\subsection{Customer Attitudes And Satisfaction On Different Retail Formats By Gender}

Various researches have investigated the impact of gender on consumer attitudes. Women and men's shopping behavior have been explained by the theory of shopping (Miller 1998). The theory argues that women's shopping behavior is really a "devotional rite" or sacrifice enacted to express love and increase the happiness and stability of the family, while shopping-as-love is not usually an accurate motivation for male shoppers. A study by Alreck and Settle (2002) stated that women find shopping and buying more satisfying or pleasurable, and/or less dissatisfying or irritating than do men.

Previous studies have explored the impact of gender effects on Internet and catalogue businesses (Alreck and Settle 2002). The study by Alreck and Settle (2002) found that women found catalogue browsing easier, more relaxing and more informative than store shopping and they were markedly more positive about the catalogue shopping experience than were men. While women tend to purchase more from catalogues than men, more men than women shop online (Flynn 2000). However, shopping over the Internet seems particularly appealing to men (Otnes and McGrath 2001). Further, Otnes and McGrath (2001) also stated that sometimes men become expert in a "feminine" area because they recognize that to do so will help them further a relationship, even if it means having to develop expertise in a "feminine" or domestic shopping arena. Shopping outlet means that men are able to distance themselves from the more feminine sphere of the marketplace and use technology as a tool for achievement, such as shopping for the best value or most feature-laden items (Otnes and McGrath 2001).

A particular concern of this study is to examine male consumers' attitudes and satisfaction levels toward online and catalogue businesses that target female products. This study also investigates how their attitudes and satisfaction differ among retail formats. Purchasing apparel as a sensory product (Kiely 1996) from direct marketing such as catalogue and e-businesses involves a certain amount of risk and effort. Therefore, this study posits that perceived ease of use and usefulness (Davis 1989) dimensions measuring perceived risk and effort before making a purchase decision are important factors with which to measure consumer attitudes and satisfaction for this study.

Hypothesis 1-i): Females' attitudes toward perceived usefulness differ from males' for pure catalogue business. Hypothesis 1-ii): Females' attitudes toward perceived usefulness differ from males' for online.

Hypothesis 1-iii): Females' attitudes toward perceived usefulness differ from males' for combination of catalogue and e-business.

Hypothesis 2-i): Females' attitudes toward ease of use differ from males' for pure catalogue business.

Hypothesis 2-ii): Females' attitudes toward ease of use differ from males' for online.

Hypothesis 2-iii): Females' attitudes toward ease of use differ from males' for a combination of catalogue and ebusiness.

Hypothesis 3): Both females' and males' attitudes toward both perceived usefulness and ease of use are higher with a combination of catalogue and e-businesses than pure catalogue or e-business.

Hypothesis 4): Females' attitudes toward willingness to purchase differ from males' for retail formats, such as catalogue, e-business, and catalogue with e-businesses.

Hypothesis 5): Females' perceived satisfaction differ from males' for retail formats, such as catalogue, e-business, and catalogue with e-businesses.

\subsection{Consumer Attitudes And Satisfaction On Different Retail Formats By Brand Familiarity}

Brand is defined as a "name, term, sign, symbol, or design, or a combination of them intended to identify the goods and services of one seller or group of sellers and to differentiate them from those of the competition (Kotler 2003)." Mohammed (2004) introduced various types of brands, such as pure online or pure offline brand, or a combination of online and offline brands. Brands are often extended to other retail formats, for example, some brands have been established as a catalogue business, then extend those to either or both online and/or offline brands.

Keller (1993) mentioned that brand knowledge consists of brand awareness and brand familiarity. Brand awareness consists of brand recognition and brand recall performance (Keller 1993). The role of brand recognition has been frequently addressed in previous studies. Brands help buyers recognize certain products that they like and dislike 
and also facilitate the purchase of items that satisfy their needs and reduce the time required purchasing the product (Pride \& Ferrell, 2003). Brand familiarity is defined as perceptions about a brand as reflected by the brand associations held in consumer memory (Keller 1993). Previous studies found that both brand awareness and familiarity play a crucial role on consumer decision-making for many reasons (Keller 1993 and Baker and Nedungadi 1986). Various researchers (e.g., Levy 1989) have proven that firms with extremely memorable brand names often regard the names as their most valuable asset because these labels provide immediate recognition, and often, acceptance of new products that may be introduced under the brand name. Similarly, Park, Jaworski, and Maclnnis (1986) restated that a well-communicated image should help establish a brand's position, insulate the brand from competition (Oxenfeldt and Swann 1964), and enhance the brand's market performance (Shocker and Srinivasan 1979). According to Baker and Nedungadi (1986), consumers think of the brand when they think about the product category. Keller (1993) stated that brand familiarity can be classified into categories, such as association from product and non-product related attributes, perceived benefits, and attitudes.

According to the definition by Baker and Nedungadi (1986), brand familiarity is a unidimensional construct that is directly related to the amount of time that has been spent processing information about the brand, regardless of the type or content of the processing that was involved. Baker and Nedungadi (1986) also state that brand familiarity is a viable independent mediator of brand liking and choice, but only in limited decision contexts. A study by Baker and Nedungadi (1986) also stated the role of brand familiarity as specific attributes/benefits and product class cues. Brand familiarity may be a viable marketing strategy if sources of evaluation (i.e., brand attribute beliefs or source credibility), which require greater information processing intensity, are not accessible or cannot discriminate between brand alternatives (Baker and Nedungadi 1986).

While many researchers have examined how brand familiarity affects consumers' willingness to purchase products online, few researchers have explored the impact of brand familiarity on catalogue businesses. Consumers $\log$ on to a certain website or have the intention to purchase products from a catalogue based on their recognition of the brand names. Previous studies found that the role of the URLs (Uniform Resource Locators), which represent the online business, is also important as online consumers recall e-commerce sites. Alba et al. (1997) mentioned that brand names could help consumers make purchase decisions in the computer-mediated environment as those enable highly reliable inferences about consumption benefits after one purchase and use. Cho and $\mathrm{Ha}$ (2004) found that brand name importantly affects consumer choice behavior in the electronic marketplace. This study hypothesizes that brand familiarity affects consumers' perceived usefulness and ease of use with both catalogue and e-businesses. Higher perceived usefulness and ease of use also affect willingness to purchase the product in both catalogues and ebusinesses. This study posits that brand familiarity is more important with look-and-feel goods and look-and-feel goods with variable quality than commodity and quasi-commodity products for both catalogue and e-businesses.

Hypothesis 6-i): Higher brand familiarity positively affects consumers' perceived usefulness than low brand familiarity for both pure catalogue and e-businesses.

Hypothesis 6-ii): Higher brand familiarity positively affects consumers' perceived usefulness than low brand familiarity for combination of catalogue and e-businesses than for pure catalogue or e-business.

Hypothesis 7-i): Higher brand familiarity positively affects consumers' perceived ease of use than low brand familiarity for both pure catalogue and e-businesses.

Hypothesis 7-ii): Higher brand familiarity positively affects consumers' perceived ease of use than low brand familiarity for combination of catalogue and e-businesses than for pure catalogue or e-business.

Hypothesis 8-i): Higher brand familiarity positively affects consumers' willingness to purchase a product than low brand familiarity for both pure catalogue and e-businesses.

Hypothesis 8-ii): Higher brand familiarity positively affects consumers' willingness to purchase a product than low brand familiarity for combination of catalogue and e-businesses than for pure catalogue or e-business.

Hypothesis 9-i): Higher brand familiarity positively affects consumers' perceived satisfaction than low brand familiarity for both pure catalogue and e-businesses.

Hypothesis 9-ii): Higher brand familiarity positively affects consumers' perceived satisfaction than low brand familiarity for combination of catalogue and e-businesses than for pure catalogue or e-business. 


\section{Theoretical Background}

Theories such as the satisfaction theory, uses and gratification theory, media richness theory, the theory of reasoned action, and Technology Acceptance Model, have been applied in this study to investigate consumers' attitudes toward different retail formats. Various satisfaction/dissatisfaction theories applied consumers' judgment on satisfaction/dissatisfaction to online customers' purchasing behavior (Cho, Il, Hiltz, and Fjermestad 2001). Contrast theory (Engel and Blackwell 1982; Howard and Sheth 1969; and Cardozo 1965), assimilation-Contrast theory (Oliver 1977), and expectation-disconfirmation theory (Oliver and Desarbo 1988) have explained customer satisfaction. Uses and gratification theory (Herzog 1944; McGuire 1974; Luo 2002) has been applied in this study to explain users' attitudes toward different retail formats. A previous study by Luo (2002) developed the theory by linking the wellgrounded uses and gratifications framework to online consumer behaviors (Luo 2002). While many studies have applied Uses and gratification theory, little has applied it to explain attitudes toward catalogue businesses. Media richness theory has also applied the uses of different medium to attitudes or behavior. The essential underlying principle in this theory is that a good match between the characteristics of a medium (media richness) and one's communication activities (such as socio-emotional activities like getting to know someone, or equivocal tasks like strategic decision making) will lead to "better" (more effective, satisfying, etc.) performance. This study posits that customers' positive attitudes will increase when they encounter richer media choices to purchase products or get information. Compared to catalogue business without online presence, catalogue with online presence will help customers' decision-making behavior. This study hypothesized that customers' willingness to purchase a product will be increased as the perceived easiness to order the products will be increased (i.e., by fax, telephone, or online).

This study also adopted the Technology Acceptance Model (TAM), which has been proposed by Davis (1989) to explain specific behavior from online businesses. Researchers have criticized the Theory of Reasoned Action (TRA) for not explaining the beliefs that are operative for a particular behavior, which is related to the usage of information technology (Succi and Walter 1999). The TAM model has been adopted in this study to describe consumer behavior in the online environment. The model explains why online users accept or reject websites and how their internal beliefs and attitudes affect their usage behavior (Davis 1989; DeSantics 1983; Ives, Olson, and Baroudi 1983). While the model has been developed to explore online businesses, this study applied it to the customer attitudes on both catalogue and e-businesses. The proposed model of this study (Figure 1) is determined by the external variables that arouse perceived ease of use and usefulness. Variables that are explored in this study include brand familiarity, gender, and various retail formats. This study also considered willingness to purchase and perceived satisfaction for different retail formats to measure attitudes toward catalogue business, e-business, and a combination of catalogue and e-businesses. This study adopted the above model to measure the impact of consumer behavior on different retail formats. In addition to the impacts proposed factors on perceived ease of use and usefulness, this study measures how perceived ease of use and usefulness affect willingness to purchase and perceived satisfaction.

Figure 1. The Proposed Model of Consumer Attitudes on Different Retail Formats (Catalogue, e-business vs. Combination of Catalogue \& e-businesses)

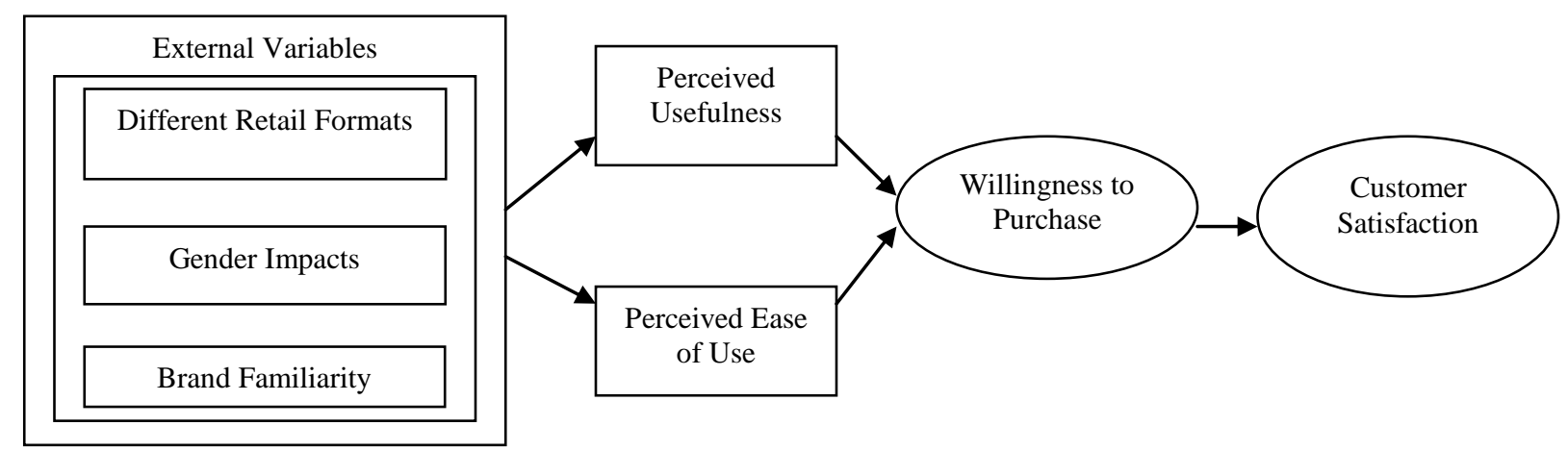




\section{Methodology}

\subsection{Overview}

This study examines how consumers' attitudes differ based on varying retail formats: pure catalogue, ebusiness, and the hybrid of catalogue and e-business. A particular concern of this study is to explore the impact of variables, such as gender, brand name, and different retail formats, on the customer's perceived ease of use and usefulness. It also measures their impact on consumers' willingness to purchase and perceived satisfaction. This study selects two brand names for both female and male-targeted sensory products. Brands V (for female) and brands $\mathrm{G}$ (for male) are selected as examples of high brand recognition, while the same brands L (for both female and male) are selected as examples of low brand recognition. The two brands chosen for customers' brand familiarities are significantly different, while perception of other product or non-product related attributes, such as price and product variety, are quite similar.

In an effort to control extraneous variables, this study conducted three experiments to explore major impacts, such as the impact of retail formats, the impact of brand name familiarity, and gender impacts. For experiment I, this study examined extraneous variables that might affect consumer attitudes toward catalogue and e-businesses. Therefore, Experiment I is designed to investigate how consumers' perceptions for different retail formats (i.e., catalogue and e-businesses) are similar for extraneous variables that are not considered in this study. Experiment II is designed to test selected brands for both female and male apparel. Experiment III, which is the main study, is designed to explore different effects of gender (female vs. male), brand name familiarity (high vs. low), and different retail formats (e.g., pure catalogue, pure e-business, vs. the combination of catalogue and e-businesses). For its main thrust, this study chooses true experiment (Aaker, Kumar, \& Day 2001) with before and after design with about six hundred randomly selected subjects. For all three designs, this study used inversely proportional sampling (Aaker, Kumar, \& Day 2001). That is, $70 \%$ female and $30 \%$ male for the evaluation of female apparel, with $30 \%$ female and $70 \%$ male for the evaluation of male apparel. Quantitative methods, such as ANOVA, regression, and chi-square analysis, have been applied to measure different consumer attitudes for various retail formats. In order to check reliability, this study measured Cronbach's alpha for multi-item scales to measure each of the main constructs that served as the basis for the questionnaire items. This study found that Cronbach's alpha for major constructs are above .80 .

\subsection{Stimulus Materials And Manipulations}

Six different pre- and post-questionnaires have been developed for two brand names and three different retail formats (i.e., catalogue, e-business, and multi-channel of catalogue and e-businesses). No separate questionnaire has been developed for each gender, while it has been asked with demographic questions. The overall design is a 3 (three different retail formats) $x 2$ (two brands for female and male: V- and L-brands for female and G- and L-brands for male) $x 2$ (gender impact) mixed design. Approximately six hundred subjects were involved in the main study (i.e. experiment III) for six different sets of questionnaire. Approximately one hundred subjects were involved in the each experiment.

\subsubsection{Experiment I: Evaluation Of Extraneous Variables}

Experiment $I$ is designed to explore extraneous variables that might affect consumer attitudes toward catalogue and e-businesses. This study considers the factors that are applied to the comparison analysis of different retail formats (Alba et al. 1997), such as price, consideration set, number of categories, information for selecting from consideration set (e.g., quantity and comparing alternatives), orders and fulfillment (e.g., delivery time and ease of ordering), convenience, customer service, and other benefits (e.g., entertainment, social interaction, and personal security). This study used the semantic differential scale to analyze how customers' perceptions on a selected brand with different retail formats are similar in terms of extraneous variables. It is expected that customers' perceptions on extraneous variables are similar between retail formats, such as catalogue and e-businesses. 
Approximately two hundred randomly selected subjects that are both graduate and undergraduate students at universities in the U.S. and also randomly selected customers/users who have experienced both catalogue and ebusiness, participated in this study. Half the subjects participated in the experiment for female apparel, while the other half of the subjects participated in the experiment for male apparel. Approximately ten catalogues are used for the experimentation (i.e., ten for High Brand Familiarity and Target to Female; ten for Low Brand Familiarity and Target to Female; ten for High Brand Familiarity and Target to Male; and ten for Low Brand Familiarity and Target to Male). Therefore, a total of forty catalogues were used for this study. Three randomly selected catalogues were assigned for each subject. After they reviewed the catalogues, subjects were instructed to go online for each brand and compare their perceptions of the product and non-product related attributes for each brand.

\subsubsection{Experiment II: Selection Of Brands}

Experiment II is designed to evaluate brands that were selected for this study. Two brands were selected for female apparel, while two other brands were selected for male apparel. Approximately two hundred randomly selected subjects that are both graduate and undergraduate students at universities in the U.S. participated in this study. This study used the Likert scale to ask how much the participants were familiar with the brands. Subjects were asked to rate the brand based on the purchase experience; brand name familiarity; product or non-product attributes, such as perceived product quality, product variety, price, information quality, product design, ease of ordering, and picture quality based on website and/or catalogue, importance of the purchase, etc. The following questions were used to recall the previous purchasing experiences and also are applied to examine how respondents' previous experiences affect the brand name familiarities.

Table 1. An Example of Questions that are used for Pre-Questionnaire

\begin{tabular}{|c|c|c|c|c|c|}
\hline & $\begin{array}{c}\text { Product } \\
\text { Names }\end{array}$ & $\begin{array}{c}\text { \# of Times Purchased } \\
\text { the product }\end{array}$ & $\begin{array}{c}\text { For } \\
\text { Whom? }\end{array}$ & $\begin{array}{c}\text { Source of Retail Formats } \\
\text { (Online/Catalogue/In-Store) }\end{array}$ & Occasion \\
\hline Example & Underwear & 3 & Girlfriend & Online & Birthday \\
\hline Item A & & & & & \\
\hline Item B & & & & & \\
\hline Item C & & & & & \\
\hline Item D & & & & & \\
\hline Item E & & & & & \\
\hline
\end{tabular}

\subsubsection{Experiment III: Main Study}

About six hundred subjects were instructed to answer a set of pre- and post-questionnaires among six different sets of questionnaires. Each subject was instructed to spend i) 15 minutes filling out the pre-questionnaire, ii) 20 minutes looking up assigned catalogues, the companies' website, or both assigned catalogues and websites, and iii) 15 minutes filling out the post-questionnaire. This study divided the participants into six different subject groups. The first subject group, assigned to the impact of catalogue only, was to spend 15 minutes to filling out the prequestionnaires and 20 minutes looking up assigned catalogues for brand $\mathrm{V}$. The second subject group, assigned to the impact of e-business only was to spend 15 minutes to filling out the pre-questionnaires and 20 minutes looking up ebusiness for brand V. After filled out pre-questionnaires, the third subject group assigned to the impact of multichannel, was to spend 30 minutes looking up both assigned catalogue and e-business for brand V. The other three subject groups were assigned the same tasks for brand G. Pre- and post-questionnaires were developed to measure the differences before and after participating in the experiments. Subjects were asked to answer both pre-and postquestionnaires after being exposed to pure catalogue, e-business, or catalogue with an online business. 


\subsubsection{Measuring Opinions Before Experiments.}

On the pre-questionnaire, this study measured and asked purchase experiences of each brand and sources of the retail format. An example of the questions that were used for pre-questionnaires is presented in Table 1. This study also asked for subjects' opinions about each sensory product, such as apparel, accessories, cosmetics, shoes, etc. This study developed the scales from previous studies. For example, scales for perceived usefulness and perceived ease of use have been developed from the previous study by Davis (1989) and Davis, Bagozzi, and Warshaw (1989). Scales for other variables were developed from studies by Succi and Walter (1999), Zhou (2002), Schubert and Selz (1999), and Chen and Wells (1999). Likert scales, Semantic differential scales, and open-ended questions were used to measure the items. For Likert scale questions, a five-point scale with extremes labeled "Strongly Disagree" and "Strongly Agree" was used. Multivariate data analyses, such as factor and regression analyses were used to analyze this study.

\subsubsection{Experiments.}

After subjects filled out the pre-questionnaire, subjects were assigned to look over catalogue businesses, online businesses, or both types of businesses. Subjects who were assigned catalogue business were to look up two randomly selected catalogues out of ten prepared catalogues for each brand. Different versions of catalogues, such as seasonal or a special version, were used for both brands. Investigators distributed notes and pencils to subjects and encouraged them to make memos for the items which they were willing to purchase.

\subsubsection{Measuring Opinions After Experiments}

After the experiment, a post-questionnaire was distributed to each subject. This study measured the number of products that subjects were interested in, their willingness to purchase, their degree of expectation to purchase the item, the reasons for their willingness to purchase, and their satisfaction with the online or catalogue businesses.

\section{Results}

\subsection{Results For Experiment I \& II}

This study found that consumers' perceptions on factors that are proposed by the previous study (Alba et al. 1997) are statistically similar for both retail formats, catalogue and e-businesses.

The study found that factors such as brand name familiarity and gender significantly affect consumers' attitudes toward catalogue and e-businesses. Chi-square has been applied to rate the product- and non-product related attributes such as price, product quality, product variety, design, information quality, picture quality, frequent promotion, and return policy to compare consumers' attitudes toward six different subject groups: two different brands for male and female in three different retail formats (i.e., pure catalogue or e-business and a combination of catalogue and e-businesses). Chi-square result shows that customers' opinions on product- and non-product related attributes offered from the same brand are similar $\left(X^{2}=2.01\right.$ for female brands and $X^{2}=1.80$; both are not significant at 0.01 level) for all three retail formats. The result of this study found that consumers overall attitudes for product attributes differ for retail formats, such as catalogue, e-business or both catalogue and e-businesses.

\subsection{Results For Experiment III}

Of the 600 respondents from the data collected for three different retail formats - 200 each for pure catalogue, e-business, and a combination of catalogue and e-businesses. For all three designs, inversely selected subjects were selected for this study. $70 \%$ female and 30\% male for the evaluation of female apparel, with $30 \%$ female and $70 \%$ male for the evaluation of male apparel. About $30-40 \%$ were between the ages $18-24$; $35 \%$ were between the ages 25 $30 ; 18 \%$ were in the $31-40$ age group; $4.5 \%$ were in the age group $41-50$; and less than $3 \%$ were age 51 or older for each of the three retail formats. Approximately $25-30 \%$ reported that their highest educational level was high school graduate, while $3-6 \%$ had an associate degree, $50-56 \%$ were college graduates, and $10-14 \%$ had done graduate work. 
More than $60 \%$ had an annual average income between $\$ 20,000$ and \$59,999. 50.3\% respondents were Asian/AsianAmerican, 23.5\% were White-American, and 7.5\% were Black/African-American. Table 2 shows respondents' descriptive statistics for groups that have applied for three different retail formats: i) Group A is exposed to purecatalogue only $(n=200)$; ii) Group B is exposed to pure e-business only $(n=200)$; and iii) Group C is exposed to both catalogue and e-businesses $(n=200)$.

This study used chi-square to test the differences for demographics from the data collected for three different retail formats. The chi-square result for "gender" differences found that there is no significant difference between the data from three different retail formats (Chi-square $=0.005 ; p<=1$ ). The study also found that there is no significant difference between the "age groups" (Chi-square $=1.666 ; p<=1$ ). The chi-square analysis of "educational level" also concluded that there is no significant difference (Chi-square $=2.656 ; p<=1)$. Chi-square analysis results for the "income" (Chi-square $=2.29 ; p<=1)$ and "cultural background" (Chi-square $=4.93 ; p<=1)$ also showed that there are no significant differences between the two data sets.

Table 2. Consumers' Attitudes Toward Different Retail Formats

\begin{tabular}{|c|c|c|c|c|c|c|c|c|c|c|c|c|}
\hline \multirow{3}{*}{ Attributes } & \multicolumn{6}{|c|}{ Female } & \multicolumn{6}{|c|}{ Male } \\
\hline & \multicolumn{3}{|c|}{ High Brand Familiarity } & \multicolumn{3}{|c|}{ Low Brand Familiarity } & \multicolumn{3}{|c|}{ High Brand Familiarity } & \multicolumn{3}{|c|}{ Low Brand Familiarity } \\
\hline & Online & Catalogue & Both & Online & Catalogue & Both & Online & Catalogue & Both & Online & Catalogue & Both \\
\hline Price & 4.2 & 4.3 & 4.5 & 4.0 & 3.9 & 4.0 & 4.0 & 4.0 & 4.1 & 3.7 & 3.6 & 3.7 \\
\hline $\begin{array}{l}\text { Product } \\
\text { Quality }\end{array}$ & 4.4 & 4.6 & 4.8 & 2.9 & 3.0 & 3.2 & 4.3 & 4.4 & 4.5 & 3.1 & 3.0 & 3.1 \\
\hline Design & 4.2 & 4.3 & 4.5 & 3.2 & 3.4 & 3.4 & 4.1 & 4.0 & 4.1 & 3.2 & 3.3 & 3.1 \\
\hline $\begin{array}{l}\text { Information } \\
\text { Quality }\end{array}$ & 4.3 & 4.7 & 4.6 & 3.5 & 3.0 & 3.4 & 4.1 & 4.2 & 4.3 & 3.4 & 3.1 & 3.3 \\
\hline $\begin{array}{l}\text { Picture } \\
\text { Quality }\end{array}$ & 4.4 & 4.9 & 4.8 & 3.2 & 3.1 & 3.1 & 4.1 & 4.3 & 4.4 & 3.0 & 3.0 & 3.1 \\
\hline $\begin{array}{l}\text { Frequent } \\
\text { Promotion }\end{array}$ & 4.1 & 4.0 & 4.5 & 2.9 & 2.4 & 2.5 & 4.1 & 4.2 & 4.5 & 2.5 & 2.3 & 2.4 \\
\hline Return Policy & 4.2 & 4.0 & 4.2 & 3.5 & 3.1 & 3.4 & 4.1 & 4.0 & 4.2 & 3.2 & 3.1 & 3.2 \\
\hline Accessibility & 4.3 & 3.9 & 4.5 & 2.9 & 2.0 & 3.0 & 4.0 & 4.1 & 4.2 & 2.5 & 2.1 & 2.6 \\
\hline Convenience & 4.0 & 3.8 & 4.1 & 2.2 & 2.2 & 2.6 & 4.3 & 4.0 & 4.1 & 2.3 & 2.1 & 2.4 \\
\hline Ease of order & 4.2 & 3.9 & 4.3 & 2.3 & 2.1 & 2.7 & 4.1 & 3.8 & 4.2 & 2.3 & 2.1 & 2.3 \\
\hline Delivery time & 3.8 & 3.9 & 4.0 & 2.6 & 2.3 & 2.7 & 4.0 & 3.9 & 4.0 & 2.3 & 2.4 & 2.4 \\
\hline $\begin{array}{l}\text { Brand } \\
\text { familiarity }\end{array}$ & 4.8 & 4.7 & 4.7 & 1.3 & 1.2 & 2.0 & 4.8 & 4.8 & 4.9 & 1.5 & 1.4 & 1.9 \\
\hline $\begin{array}{l}\text { Customer } \\
\text { service }\end{array}$ & 4.1 & 4.0 & 4.1 & 1.5 & 1.5 & 1.8 & 4.0 & 4.0 & 4.1 & 1.3 & 1.4 & 1.6 \\
\hline Entertainment & 4.6 & 4.8 & 4.7 & 2.0 & 2.1 & 2.4 & 4.5 & 4.8 & 4.7 & 1.9 & 1.8 & 2.0 \\
\hline
\end{tabular}

Table 2 provides results for customers' perceived familiarity of the product- and non-product related attributes after they recognize the brand name. Compared to the results from experiment I and II, this study found that customers perceived familiarity of various attributes are higher with a high familiarity brand than lower familiarity brand for both female and male brands (see also figure $3 \& 4$ ). This study used the semantic differential scale to measure consumers' opinions on attributes. This study used a five-point scale with a lower number for negative opinions and a higher number for positive opinions except the price factor (e.g., 1 - negative; 5 - positive). That is, higher score for product quality implies that product quality is higher, while lower score for price implies that perceived price is lower. 
Figure 2. Consumers' Attitudes toward Different Retail Formats

(Pure Catalog, E-Business vs. Combination of Catalog and E-Business: Female Case)

\begin{tabular}{|l|l|l|l|l|l|}
\multicolumn{1}{c|}{ Low Brand Familiarity (Catalogue) } \\
Low Brand Familiarity (Both)
\end{tabular}

The results of this study (Figure $2 \& 3$ ) show that two selected brands for female and male apparel are significantly different in terms of overall attitudes. As shown on the following profile analyses, customers' attitudes are quite similar, but slightly different for brand familiarity for three different retail formats (pure catalogue, pure ebusiness and combination of catalogue and e-businesses). This study also found that consumers' attitudes toward familiarities on price, quality, information quality, accessibility, convenience, and ease of order are higher when consumers are exposed to both catalogue and e-business rather than pure catalogue or e-business. This finding was also the same for both female and male cases.

This study analyzed simple linear regression analyses and the analyses of variance (ANOVA). First, this study used regression analyses for the impacts of predictors to perceived usefulness and ease of use. Four brand names and three different retail formats were considered in this study (see table $3 \& 4$ ). The results of the analysis of variance find all models significant at .01 level (two-tailed) and $r$-squares show higher than .60. Table 3 shows the impact of different retail formats and brand name familiarity on usefulness and ease of use for female case, while table 4 shows for male case. This study found gender differences in catalogue and online shopping behavior. This study accepted the hypotheses $1-i, i i$, \& iii and $2-i, i i \& i i i$ as the following tables (table $3 \& 4$ ) show that females' attitudes toward both perceived usefulness and ease of use differ from males' for all three retail formats, such as pure catalogue, ebusiness and the combination of catalogue and e-businesses. The study found that females' attitudes such as perceived ease of use and usefulness toward catalogues is higher than for online businesses. Its impact is higher with high brand familiarity rather than low brand familiarity $(6-i \& 7-i)$. It is also found that male's attitudes such as perceived ease of use and usefulness toward online businesses are higher than female's, while females' attitudes such as perceived ease of use and usefulness toward catalogues are higher than males'. Both female and male's attitudes toward both perceived usefulness and ease of use are higher with a combination of catalogue and e-businesses than pure catalogue or e-business. Therefore, we accept hypothesis 3 . As hypothesized $(6-i i \& 7-i i)$, this impact is higher with high brand familiarity rather than low brand familiarity. 
Figure 3. Consumers' Attitudes toward Different Retail Formats

(Pure Catalog, E-Business vs. Combination of Catalog and E-Business: Male Case)

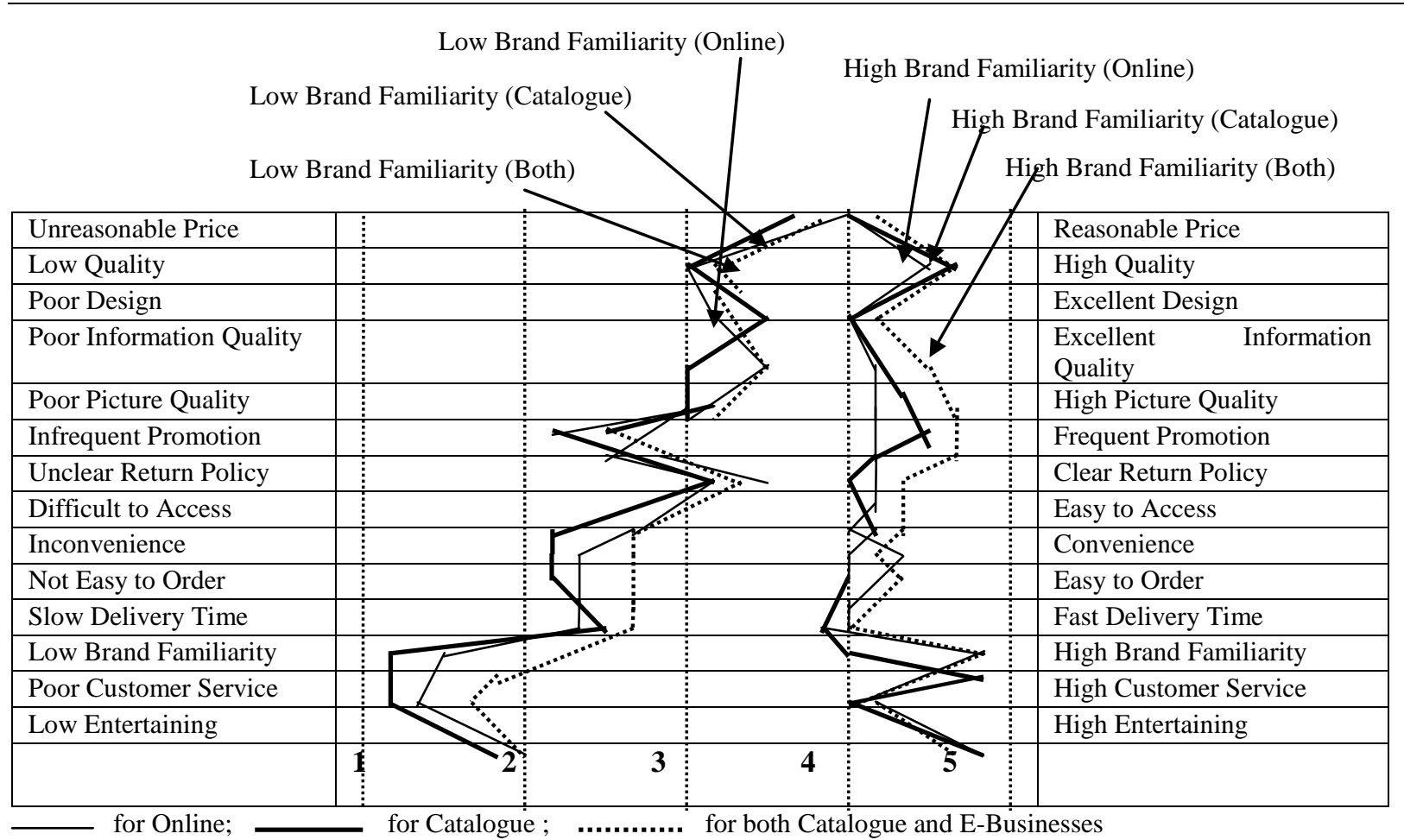

Table 3. The Impact of Different Retail Formats and Brand Name Familiarity on Usefulness and Ease of Use (Case of Female)

\begin{tabular}{|c|c|c|c|c|c|c|}
\hline & \multicolumn{2}{|c|}{ Online } & \multicolumn{2}{c|}{ Catalogue } & \multicolumn{2}{c|}{ Both } \\
\cline { 2 - 7 } & $\mathbf{H}$ & L & H & L & H & L \\
\hline U & $.312\left(4.071^{* *}\right)$ & $.201\left(2.911^{*}\right)$ & $.361\left(4.889^{* *}\right)$ & $.210(2.989 *)$ & $.380\left(4.981^{* *}\right)$ & $.257\left(3.471^{*}\right)$ \\
\hline EOU & $.311\left(4.011^{* *}\right)$ & $.214\left(3.011^{*}\right)$ & $.321\left(4.211^{*}\right)$ & $.217\left(3.113^{*}\right)$ & $.319(4.105 * *)$ & $.227\left(3.215^{*}\right)$ \\
\hline
\end{tabular}

** Significant at 0.01 level (2-tailed); * Significant at 0.05 level (2-tailed).

Table 4. The Impact of Different Retail Formats and Brand Name Familiarity on Usefulness and Ease of Use (Case of Male)

\begin{tabular}{|c|c|c|c|c|c|c|}
\hline & \multicolumn{2}{|c|}{ Online } & \multicolumn{2}{c|}{ Catalogue } & \multicolumn{2}{c|}{ Both } \\
\cline { 2 - 7 } & $\mathbf{H}$ & L & H & L & H & L \\
\hline U & $.353(4.642 * *)$ & $.289\left(3.511^{*}\right)$ & $.310(4.001 * *)$ & $.210\left(3.221^{*}\right)$ & $.330(4.612 * *)$ & $.241(3.017 *)$ \\
\hline EOU & $.360(4.779 * *)$ & $.271(3.479 *)$ & $.301\left(3.898^{*}\right)$ & $.220(3.319 *)$ & $.332(4.419 * *)$ & $.233(3.167 *)$ \\
\hline
\end{tabular}

** Significant at 0.01 level (2-tailed).

* Significant at 0.05 level (2-tailed).

This study also accepted hypotheses 4 that measured customers' willingness to purchase based on three retail formats are higher for females than males. Studies found that females' willingness to purchase a product is higher with catalogues than males', while males' willingness to purchase a product is higher with online businesses than females' (hypothesis 4). The results of the analysis of variance found the models significant at .01 level with $F=16.124$ (twotailed, $r$-square $=.710)$. Studies also found that female consumers' perceived satisfaction on sensory product category is higher with a high brand familiarity for all three retail formats than male's. The study also measures whether 
consumers' perceived satisfaction is higher with the combination of catalogue and e-businesses than pure catalogue and e-businesses. As hypothesized $(8-i)$, higher brand familiarity positively affects customers' willingness to purchase a product than low brand familiarity for both pure catalogue and e-businesses. It is also found that as brand familiarity is higher, consumers' willingness to purchase a product is high with both the combination of catalogue and e-businesses than single retail formats $(8-i i)$. The results of analysis of variance found that overall, the regression model is significant $(F=13.041$, significant at .01 level, two-tailed, $r$-square $=.699)$. It is also found that higher brand familiarity positively affects customers' perceived satisfaction than low brand familiarity for both pure catalogue and e-business (hypothesis $9-i$ ). Customers' perceived satisfaction shows higher with combination of catalogue with ebusiness than with pure catalogue and e-business for higher brand familiarity rather than for low brand familiarity ( 9 ii).

\section{Conclusion}

The author posits that particularly with direct marketing, such as catalogue and e-business, as customers are not able to try, touch, see, and hear the product, customers have encountered decision-making problems. It has been addressed that decision-making with look-and-feel products is even harder than with commodity products. This study views that hybrid approach of brick and mortar and "click and mortar" businesses affect customers' attitudes and decision-making behavior. While customers in both the catalogue and e-business environment cannot easily make purchase decisions on sensory products, customers' attitudes and behavior are shown to be quite different. Therefore, in this paper, the author questioned whether customers' attitudes toward catalogue and e-businesses differ for sensory products (e.g., clothes) and also whether the multi-channel improves customer willingness to purchase or their perceived satisfaction.

This study developed a theory and model for how consumers' attitudes differ based on various retail formats: pure catalogue and pure e-business vs. multi-channel of catalogue and e-businesses. This study investigated how customer perceptions and attitudes differ based on retail formats. The impacts of factors, including brand name familiarity and gender, on customers' attitudes toward perceived usefulness and ease of use were examined. This study also investigated how customers' attitudes toward perceived usefulness and ease of use affect customers' willingness to purchase and perceived customer satisfaction.

Major findings suggest that businesses dealing with sensory products should manage multi-retail formats to improve customers' willingness to purchase and also that these retailers should provide higher quality information. This study also found that females are more willing to purchase sensory products through catalogue businesses, while males prefer online businesses. The study found that customers' perceived ease of use, usefulness, and willingness to purchase the sensory products are higher with multi-channel (i.e., catalogue with e-businesses) than pure catalogue or e-businesses. However, it was also found that male customers' willingness to purchase a sensory product online was not higher than with female customers.

The findings of the study contribute to the development of the theories, while also providing implications and suggestions to catalogue and e-businesses. This study contributes to both theory and model development. This study extends theories of attitudes and behavior both in the online and catalogue business environments. Since not many studies have explored customers' perceptions and attitudes for multi-retail formats and compared them with pureplays, there are opportunities for future research. Future research could measure customer dissatisfaction and complaints on different retail formats. Customer perceptions and willingness to purchase from other retail formats rather than catalogue businesses, such as physical stores, could be the subject of further research. Future researchers should consider and analyze other factors, such as benefits from retail formats including entertainment, social interaction, and personal security that have been addressed by Alba et al. (1997).

The study has some limitations. There might be interaction effects as this study chose true experimental design with before and after designs. While this study conducted experiments to prove extraneous variables that are similar for both online and catalogue businesses, other studies could consider other variables that might affect both retail formats. Future studies could measure actual behavior, which is the last stage from the Fishbein model after the 
behavioral intentions. This study used subjects that are undergraduate and graduate students. Future studies could be applied to general customers that are used to shopping in both online and catalogue businesses.

\section{References}

1. $\quad$ Aaker, D. A., V. Kumar, and G. S. Day, Marketing Research, $7^{\text {th }}$ ed., John Wiley and Sons, Inc. 2001.

2. Ajzen, I. and M. Fishbein, Understanding Attitudes and Predicting Social Behavior Englewood Cliffs, NJ, Prentice-Hall, 1980.

3. Alba, J., J. Lynch, B. Weitz, C. Janiszewski, R. Lutz, and S. Wood, Interactive Home Shopping: Consumer, Retailer, and Manufacturer Incentives to Participate in Electronic Marketplaces, Journal of Marketing, Vol. 61, pp. 38-53, July 1997

4. Alreck, P. and S. Robert, Gender Effects on Internet, Catalogue, and Store Shopping, Journal of Database Marketing, January, Vol. 9, Issue 2, pp. 150-63, 2002.

5. Baker, W. J. and P. Nedungadi, Brand Familiarity and Advertising: Effects on the Evoked Set and Brand Preferences, Advances in Consumer Research, 13. Richard J. Lutz, ed. Provo, UT: Association for Consumer Research, 1986.

6. Cardozo, R. N., An Experimental Study of Customer Effort, Expectation, and Satisfaction, Journal of Marketing Research, Vol. 2, pp. 244-49, August, 1965.

7. Cho, Y. and Fjermestad J. (2005), Using eCCRM to Maximize/Minimize Customer Satisfaction/Dissatisfaction, Advances in Management Information Systems: Special Issue on Customer Relationship Management, (Summer).

8. Cho, Y. and J. Ha, Users' Attitudes Towards Movie-Related Websites and E-Satisfaction, Journal of Business \& Economics Research, March, 2004.

9. Cho, Y., Im, Il, S. Hiltz, \& J. Fjermestad, The Effects of Post-Purchase Evaluation Factors on Online vs. Offline Customer Complaining Behavior: Implications for Customer Loyalty, Advances in Consumer Research, Vol. 29, Association for Consumer Research, 2001.

10. Davis, F. D., Perceived Usefulness, Perceived Ease of Use, and User Acceptance of Information Technology, MIS Quarterly, Vol. 13, Issue 3, pp. 319-340, September, 1989.

11. DeSantis, G. Expectancy Theory as an Explanation of Voluntary Use of a Decision Support System, Psychological Reports, Vol. 52, pp. 247-260, 1983.

12. Duffy, V. G., Yen, B. P., and Cross, G. W. (2004), Internet Marketing and Product Visualization (IMPV) System: Development and Evaluation in Support of Product Data Management, International Journal of Computer Integrated Management, Vol. 17, No. 1, pp. 1-15.

13. Figueiredo, J. M.de., Finding Sustainable Profitability in Electronic Commerce, Sloan Management Review, pp. 41-52, Summer, 2000.

14. Fishbein, M. and I. Ajzen, Belief, Attitude, Intention and Behavior, MA: Addison-Wesley, 1975.

15. Flynn, L. J., Women Pass Men in Internet Use, New York Times, 9, C6, August, 2000.

16. Engel, J. F., R. D. Blackwell, and P. W. Miniard, Consumer Behavior, $8^{\text {th }}$ ed., Dryden Press, 1986.

17. Hansotia, B. J. and Rukstales, B. (2002), Direct Marketing for Multichannel Retailers: Issues, Challenges, and Solutions, Journal of Database Marketing, Vol. 9, No. 3, pp. 259-266.

18. Herzog, H., What Do We Really Know About Day-Time Serial Listeners? Radio Research, Paul F. Lazarsfeld and Frank N. Stanton, eds., New York: Duel, Sloan and Pearce, 1944.

19. Hiltz, S. R. and M. Turoff, The Network Nation: Human Communication via Computer, Reading, MA: Addison Wesley, 1978.

20. Hoffman, D. L. and T. P. Novak, Marketing Pornography on the Information Superhighway, A detailed analysis of the conceptual, logical, and methodological flaws in the article, June, Project 2000, Owen Graduate School of Management, Vanderbilt University, version 1.01, 1995 [available at http://ecommerce.vanderbilt.edu/novak/rimm.review.html].

21. Howard, J. A. and J. N. Sheth, The Theory of Buyer Behavior, New York, John Wiley and Sons, 1969.

22. Ives, B., M. H. Olson, and J. J. Baroudi, The Measurement of User Information Satisfaction, Communications of the ACM, Vol. 26, Issue 10, pp. 785-793, 1983.

23. Keller, K. L., Conceptualizing, Measuring, and Managing Customer-based Brand Equity, Journal of Marketing, Vol. 57, Issue 1, pp. 1-22, 1993.

24. Kiely, T., The Pleasures and Perils of Selling in Cyberspace, Insights from Marketing Science Institute, Winter/Spring 1997, Reprinted by Permission of Harvard Business Review in Briefings from Editors, SeptemberOctober, 1996. 


\section{"Look and}

Feel" Goods with Variable Quality

25. Korgaonkar, P. K. and L. D. Wolin, A Multivariate Analysis of Web Usage, Journal of Advertising Research, pp. 53-68, March/April, 1999.

26. Kotler, P., Marketing Management, $11^{\text {th }}$ edition, Prentice Hall, ISBN: 0-13-047645-5, 2003.

27. Levy, M. J., The influence of a brand name's association set size and word frequency on brand memory, Journal of Consumer Research, Vol. 16, Issue. 2, October, 1989.

28. Luo, X., Uses and Gratifications Theory and E-Consumer Behaviors: A Structural Equation Modeling Study, Journal of Interactive Advertising, Vol. 2, Issue. 2 Spring, 2002.

29. Mathwick, C., N. Malhotra, and E. Rigdon, Experiential Value: Conceptualization, Measurement, and Application in the Catalog and Internet Shopping Environment, Journal of Retailing, Vol. 77, pp. 39-56, 2001.

30. Mcguire, W. J., Psychological Motives and Communication Gratification: The Uses of Mass Communications, Jay G. Blumler and Elihu Katz, eds., Beverly Hills, CA: Sage Publications, 1974.

31. Miller, D., A Theory of Shopping, Ithaca, NY: Cornell University Press, 1998.

32. Mitchell, A. A. and J. C. Olson, Are Product Attribute Beliefs the Only Mediator of Advertising Effects on Brand Attitude? Journal of Marketing Research, Vol. 18, pp. 318-32, August, 1981.

33. Mohammed, R. A., R. J. Fisher, B. J. Jaworski, and A. M. Cahill, Internet Marketing: Building Advantage in a Networked Economy, McGraw-Hill Irwin, Marketspace U, $2^{\text {nd }}$ edition, 2004.

34. Oliver, R. L., Effect of Expectation and Disconfirmation on Post-Exposure Product Evaluations: An Alternative Interpretation, Journal of Applied Psychology, Vol. 62, pp. 480-486, August, 1977.

35. Oliver, R. L. and W. S. DeSarbo, Response Determinants in Satisfaction Judgments, Journal of Business Research, Vol. 14 pp. 495-507, March, 1988.

36. Oxenfeldt, A. R. and C. Swann, Management of the Advertising Function. Belmont, CA: Wadsworth Publishing Co, 1964.

37. Park, C. W., J. J. Bernard, and J. M. Deborah, Strategic Brand Concept-familiarity Management, Journal of Marketing, Vol. 50, pp. 135-45, October, 1986.

38. Pride, W. M. and O. C. Ferrell, Branding and Packaging in Marketing, Boston: Houghton Mifflin Company, pp. 297-98, 2003.

39. Rice, R. E., Media Appropriateness: Using Social Presence Theory to Compare Traditional and New Organizational Media, Human Communication Research, Vol. 19, Issue 4 pp. 451-484, June, 1993.

40. Rice, R. E. and G. Love, Electronic Emotion: Socio-emotional Content in a Computer-Mediated Communication Network, Communication Research, Vol. 14, Issue 1, pp. 85-108, February, 1987.

41. Otnes, C. and M. A. McGrath, Perceptions and Realities of Male Shopping Behavior, Journal of Retailing, Vol. 77, Issue 1, pp. 111-138, Spring, 2001.

42. Schubert, P. and S. Dorian, Web Assessment: Measuring the Effectiveness of Electronic Commerce Sites Going Beyond Traditional Marketing Paradigms, Proceedings of the $32^{\text {nd }}$ Hawaii International Conference on System Sciences, 1999.

43. Shocker, A. D. and V. Srinivasan, Multiattribute Approaches for Product Concept Evaluation and Generation: A Critical Review, Journal of Marketing Research, Vol. 16 pp. 159-80, May, 1979.

44. Succi, M. J. and Z. D. Walter, Theory of User Acceptance of Information Technologies: An Examination of Health Care Professionals, Proceedings of the $32^{\text {nd }}$ Hawaii International Conference on System Sciences, Hawaii, 1999.

45. Vargas, M., Retail Apparel Sales Statistics and Trends 2000. Retrieved on October 20, 2003, [available at http://retailindustry.about.com/library/weekly/01/aa010319a.htm].

46. Wilkie, W. L. and A. P. Edgar, Issues in Marketing's Use of Multi-Attribute Attitude Models, Journal of Marketing Research, Vol. 10, pp. 428-41, November, 1973.

47. Zhou, Z., Users' Attitudes Toward Web Advertising: Effects of Internet Motivation and Internet Ability, Advances in Consumer Research, Vol. 29, pp. 71-78, Association for Consumer Research, 2002.

48. Zoltan, E. and A. Chapanis, What Do Professional Persons Think About Computers, Behaviour and Information Technology, Vol. 1, Issue 1 pp. 55-68, January - March, 1982.

\section{Online Resources:}

http://www.bcg.com http://www.catalogagemag.com http://www.dma.com http://retailindustry.about.com/library/bl/q2/bl_dma060401a.htm http://www.theStandard.com 